Georgia State University

ScholarWorks @ Georgia State University

\title{
Urban Life in the Shadows of Infrastructural Death: From People as Infrastructure to Dead Labor and Back Again
}

Jean-Paul Addie

Georgia State University, jaddie@gsu.edu

Follow this and additional works at: https://scholarworks.gsu.edu/urban_studies_institute

Part of the Urban Studies and Planning Commons

\section{Recommended Citation}

Addie, Jean-Paul, "Urban Life in the Shadows of Infrastructural Death: From People as Infrastructure to Dead Labor and Back Again" (2021). USI Publications. 53.

doi: https://doi.org/10.1080/02723638.2021.1902633

This Article is brought to you for free and open access by the Urban Studies Institute at ScholarWorks @ Georgia State University. It has been accepted for inclusion in USI Publications by an authorized administrator of ScholarWorks@ Georgia State University. For more information, please contact scholarworks@gsu.edu. 


\title{
Urban Life in the Shadows of Infrastructural Death: From People as Infrastructure to Dead Labor and Back Again
}

\author{
Jean-Paul D. Addie \\ Urban Studies Institute \\ Georgia State University \\ 55 Park Place 849D, Atlanta, Georgia, USA 30303 \\ e: jaddie@gsu.edu | p: +1 4044130190
}

Paper prepared for Urban Geography Debates and Interventions on 'People as Infrastructure' 


\section{Urban Life in the Shadows of Infrastructural Death: From People as Infrastructure to Dead}

\section{Labor and Back Again}

Abstract: Grounded in the writings of AbdouMaliq Simone and the theoretical project of Southern urbanism, the concept of 'people as infrastructure' has radically reframed how we understand and study urban infrastructure as a modality of social practice. This paper begins by appraising the impact that people as infrastructure has had on urban geography and critical infrastructure studies before moving to consider how notions of infrastructural violence can deepen our understanding of the concept's content and context. In particular, this intervention brings people as infrastructure into dialogue with the Marxist concept of 'dead labor' to bridge experiential and structural epistemic readings of infrastructure as human practice and as a product of social labor. Doing so, I suggest, provides a novel conceptual and political terrain to: (1) highlight the 'living labor' underpinning the production of socio-technical systems; and (2) think through how urban lives and livelihoods may transform and transgress the 'infrastructural alienation' generated by capitalist urbanization.

Keywords: alienation, dead labor, infrastructure, infrastructural violence, urban theory

The analysis of infrastructure has come a long way since Susan Leigh Star implored us to "study boring things" and unearth the inherent dramas to be found within infrastructure's "singularly unexciting... lists of numbers and technical specifications" (1999, p. 377). Over the past two decades, an encompassing 'infrastructure turn' across the social and policy sciences has expanded the conceptual, analytical, and methodological toolkits researchers use to assess the complex, situated, and fundamentally political "ways in which infrastructures, cities and nation states are produced and transformed together" (McFarlane and Rutherford, 2008, p. 364). Within urban geography, critical political-economy scholarship has confronted a global shift towards infrastructure-led development and financing; deepening our understanding of infrastructure's role in enhancing territorial competitiveness (Dodson, 2017; Jonas, While, and Gibbs, 2010; Schindler and Kanai, 2021; Wiig and Silver, 2019) and intensifying capitalism's crisis tendencies (Arboleda, 2020; Kirkpatrick and Smith, 2011; O’Brien, O’Neill, and Pike, 2019; Wiig and Silver, 2019). At the 
same time, urbanists informed by southern thinking on urbanism and informality have highlighted the incremental and improvised ways in which infrastructure shapes, and is remade through, prosaic acts of everyday social practice (Anand, 2017; Coss-Corzo, 2020; Pilo’ and Jaffe, 2020). In foregrounding the social, affective, and political dimensions of infrastructural life in a state of becoming, such post-colonial work has disrupted monistic readings of socio-technical systems by disclosing the co-presence of heterogeneous infrastructural epistemologies located between fragmentation and order (Niranjana, 2021), risk and power (Lawhon et al., 2018), and decay and repair (Ramakrishnan, O’Reilly, and Budds, 2020).

The concept of 'people as infrastructure' has been notably influential within this milieu, in no small part due to how it expands the notion of infrastructure "directly to people's activities in cities... [the] incessantly flexible, mobile, and provisional intersections of residents that operate without clearly delineated notions of how the city is to be inhabited and used" (Simone, 2004, p. 407). This is a significant reconceptualization. Not only does it decenter state-centric accounts of service provision that privilege the technological dimensions of infrastructure and presumed universal access to resources (Kooy and Bakker, 2008; Silver, 2019; Tonkiss, 2013) but it presents a profound ontological challenge to the study of infrastructure, political practice, and urban ways of life.

In this paper, I offer an assessment of the impact that people as infrastructure has had on urban geography and critical infrastructure studies before turning to consider how notions of ‘infrastructural violence’ (Rodgers and O’Neill, 2012) can contextualize, reframe, and extend our understanding of the concept's utility. My argument here is that subaltern associations, livelihoods, and infrastructural practices exist in dialectical tension with the specter of infrastructural death: both in terms of bodily experiences of 'premature death' (Tyner, 2019), and through the oppressive persistence of the 'dead labor' ossified infrastructural landscapes (Mitchell, 2000, 2003). Bringing 
people as infrastructure into dialogue with the Marxist concept of dead labor, I argue, offers generative grounds to grapple with the "cruelty as well as promise" of urban infrastructure (Amin and Thrift, 2017, p. 6); exposing the structural conditions that necessitate the performance of subaltern social infrastructure while also helping us think through how to confront the production and experience of 'infrastructural alienation'.

\section{Opening the Church of Infrastructure Studies}

The 'infrastructure turn' has fostered an ecumenical reading of its central object of analysis - one that transcends the seemingly banal world of technical systems to incorporate the intangible networks and governance regimes that enable their everyday use, regulation, and maintenance (Addie, Glass, and Nelles, 2019; Filion and Keil, 2017; McFarlane and Rutherford, 2008). Yet while notions of infrastructure (even within much Southern urbanism) remain normatively attached to some form of constructed material artefact "with physical properties and pragmatic properties in its effects on human organization" (Star, 1999, p. 387), people as infrastructure sheds this direct connection to infrastructures' materiality. Instead, AbdouMaliq Simone's (2004, 2018) provocation finds the work of infrastructure being animated in the 'uncertain operations' and 'uncanny alliances' lived by poor and working people in the urban South. Rather than conceiving infrastructure as "matter that enable the movement of other matter" (Larkin, 2013, p. 329), we are being asked to view infrastructure as social practice: "a kind of mentality and way of living in the world" (ibid, p. 331).

Critics warn such maneuvers risks conceptual slipperiness and theoretical overextension that strips infrastructure of its analytical utility, creating "a signifying apparatus that would mean everything and nothing all at once" (Howe et al., 2016, p. 558, also see Edwards, 2003, pp. 186-187). Yet this view only holds if we approach infrastructure as a material set of objects-in-the-world. If we take the central intervention of people as infrastructure as a theoretical proposition, we encounter a 
conceptual provocation that challenges us to assess what infrastructure is, and what is necessary to make particular ways of being-in-the-world possible. Here, people as infrastructure orients us towards the practices and networks through which marginalized and forgotten communities construct their lives in the absence, or wake, of formal systems of resource provision. In this light, I see its impacts resonating across the 'infrastructure turn' in several key registers.

First, people as infrastructure has empirically and analytically pushed our infrastructural imaginaries beyond the world of engineered systems (understood through rational, technocratic knowledge) to the precarious, improvisational, and ephemeral processes through which 'incomplete' cities are continually remade (Calderia, 2017; Doherty, 2017; Maringanti and Jonnalagadda, 2015). Infrastructure, for Simone, emerges as a "complex combination of objects, spaces, persons, and practices" that reconstitute urban life on an everyday basis (2004, p. 408). In the everyday city, seemingly solid systems and technologies are rendered mutable in the face of dynamic modes of existence that they cannot fully contain. Here, social infrastructure "is not just a context or a noun, but a verb... made and held stable through work and changing ways of connecting" (McFarlane and Silver, 2017, p. 463). Post-colonial encounters with infrastructure consequently engender: (1) an ontological assertion regarding socio-spatial contingency; and (2) an epistemological mandate to validate the marginalized places, people, and practices that are foundational to the reproduction of urban life (Lawhon and Truelove, 2020). By decentering normative assumptions regarding built forms and civic responsibility in making cities work, people as infrastructure elevates adaptable collaboration and provisional socio-economic assemblages, which are often more immediate, intelligible, and useful to those on the street.

Second, in methodological terms, people as infrastructure has prompted researchers, activists, and policy-makers to practice new ways of seeing at the intersection of standardization and improvisation. We are directed to 'the background' as both cognitive construct and a continuously 
changing "actual terrain, something which is engaged, navigated, and acted upon" (Simone, 2019, p. 991). Amidst the interdisciplinary infrastructural work emerging at the interface of urban geography, anthropology, and sociology, Simone's (2004) commitment to providing thick descriptions of Johannesburg streets has helped validate ethnography as vital strategy to illuminate the lives and livelihoods that sustain essential in/formal urban infrastructures (see Anand, Gupta, and Appel, 2018; Graham and McFarlane, 2015). Research exploring people as infrastructure has contributed to the burgeoning 'ethnographies of infrastructure' literature (Hearne, Holbrand, and Wastell, 2007; Larkin, 2013; Star, 1999) that richly describes the materials, policies, and people turning on (and off) water supplies in Mumbai and Chennai (Anand, 2017; Niranjana, 2021), generating and maintaining electricity systems in Dar es Salaam (Degani, 2018), providing sanitation services in Nairobi (Thieme, 2015), mobilizing highway construction across South America (Harvey and Knox, 2016), and irrigating agricultural space across the Nile Valley and Delta (Barnes, 2017), amongst others.

Third, while much work mobilizing a people as infrastructure framework takes its lead from scholarship on and from metropolises in the Global South, bringing the concept - as a modality of incomplete Southern urbanism - into conversation with wider strands of post-colonial theory and urban political ecology has enabled us to discern the lived realities of (fragmented, improvised, inequitable) Southern urbanism underpinning the reproduction of cities across the Global North (Roy, 2009; Silver, 2019). People as infrastructure has therefore a productive framework for critical and comparative global urban studies. Kinder's (2016) work on DIY urbanism in Detroit, for instance, viscerally discloses how the functioning of people as infrastructure arises in the interstices of neoliberalized service provision and the disciplinary structures of the American 'Black City' (McKittrick, 2011; Simone, 2020). Tonkiss (2013, p. 322) comparably finds space for a more-worldly 'ameliorative urbanism' in the cracks of austerity urbanization across a varied of European contexts, 
via the appropriation of uncommitted or vacant sites in the city and the emergence of alternative strategies of urban service and resource provision.

Finally, beyond an ethnographic validation of the strategies and networks people use to realize the necessities of life on the periphery (socially and spatially), engaging people as infrastructure ultimately problematizes how the relationality of infrastructure confers and denies forms of urban citizenship, participation, and political empowerment (see Anand, 2017; Lemanski, 2020; Sultana, 2020). Because everyday interactions with infrastructure form the foundations of large-scale social formations (Angelo and Hentschel, 2015), viewing infrastructure's ontological certainties as fragmented, incomplete, and dynamic opens conceptual and political space to understand how poor and working people (re)learn and (re)claim the city (Chattopadhyay, 2012; Ranganathan, 2014). While often constrained by limited financial resources or institutional capacities, people as infrastructure points to differing urban futures grounded in novel modalities of political practice and resistance as they emerge in the performativity of social relations as infrastructure (Simone, 2015). Subaltern social infrastructures are therefore not only essential for reproducing the lifeworlds of the urban poor, but for illuminating ways of resisting the violence of empire and capital shaping the urban condition in both the Global South and North (Cowen, 2020; Enns and Bersaglio, 2020; Kipfer, 2018).

As a conceptual framework, people as infrastructure privileges explorations of how urban inhabitants render life possible in the incomplete city. Yet this everyday epistemological vantage point leaves open some important conceptual and political questions regarding the essence of our relationship with infrastructure and the material, social, and structural conditions that engender such subaltern forms of infrastructural practice. One of the essential political tasks of the infrastructure turn' (evinced in much infrastructural ethnography) is rendering visible the labor through which infrastructure is produced, maintained, contested, and claimed. The remainder of this paper 
contributes to this agenda by exploring the following corollary: what might it mean to take seriously the idea of viewing infrastructure 'as people' in bodily and collective terms? In particular, I employ a historical materialist reading to conceptualizes infrastructures, and the social, political, economic, and cultural contexts in which they exist, as both human practice and products of social labor.

\section{Matters of Infrastructural Life and Death}

The social infrastructures developed by residents in the marginal spaces of the city make viable forms of inhabitation - and even transformative political imaginaries and action - possible (Simone, 2015). Yet the adaptive, improvised, and anticipatory practices captured by people as infrastructure are perennially confronted with explicit and systemic moments of violence and dispossession (Graham and McFarlane, 2015, p. 3). Stating this is not to diminish the opportunities, agency, and power to be found in the fissures of the city, or reduce the experience of marginalized residents to those of victimized 'have-nots' (McKittrick, 2011). But in the face of on-going privatization, commodification, militarization, and urbicide (Coward, 2008; Graham, 2010; McKittrick, 2011) it is incumbent to understand how and why infrastructural life is shadowed by infrastructural death. To this end, we can extend how we see infrastructure emerging from peoples' activities by thinking about urban infrastructure as internalizing human labor. Because the very precarity of improvised urban infrastructure presupposes what Tyner (2019) terms a 'political economy of violence', it is at this juncture that I want to bring people as infrastructure into dialogue with the notions of infrastructural violence and Marxist theories of alienation and dead labor.

\section{Embodying Violence}

Rodgers and O’Neill introduced the concept of 'infrastructural violence' as an ethnographic concern to identify the "socially produced wrongs that occur through the workings of what are 
unambiguously collectively 'owned' networks, by virtue of the fact of living within a shared social space” (2012, pp. 405-406). The relationship between violence and labor in infrastructural landscapes is most vicserally present in the specter of 'premature death' (Tyner, 2019, p. xi); a process (when dying starts) and event (when the dying process ends) that bodies are exposed to as a general condition of capitalism's exploitative living and working conditions (see Andueza, Davies, Loftus, and Schling, 2020; Mitchell, 2012). Doherty's (2017) study of motorcycle taxis in Kampala is instructive here. In examining the enduring nature of informal mobility in that city's transportation systems, he posits infrastructural violence as an essential component of people as infrastructure to capture both the economic precarity and embodied disposability of life on the margins, and the mutual obligations, solidarity, and vitality forged in this shared urban experience. Gabrys (2011) is similarly incisive in documenting the bodily risks and exposures undertaken by the assembly-line workers and e-waste handlers who maintain the ostensibly placeless infrastructures of the digital age. And shifting scalar registers, Cowen (2014, pp. 96-100) positions the 'body as battleground' within the infrastructures of global trade, detailing how broken bodies and premature death (from accidents on the job to exposures to toxins and HIV) become reduced to mere inherent disruptions to just-intime production.

The notion of infrastructural violence, though, not only discloses active moments where violence has a clear articulation, intent, and subject, but instances where violence is concretized in the systematic physical and political exclusion of groups and individuals from urban amenities (Rodgers and O’Neill, 2012). Such processes of omission are essential in generating the "underdeveloped, overused, fragmented, and often makeshift urban infrastructure" that marginalized communities have to compensate for (Simone, 2004, p. 425). People as infrastructure highlights the 'flexible configurations' emerging in places with a dearth of physical infrastructure and ample inexpensive labor (ibid, pp. 410-411). Yet physical infrastructure is never entirely lacking or 
absolutely absent. 'Infrastructure deserts' appear in relative terms that reflect differentiated or splintered service provision (Filion and Keil, 2017, p. 9; Graham and Marvin, 2001). Even places without direct access to sanitation, fresh water, or mobility systems are haunted by the phantom traces of withdrawn services or the promise of unrealized development in the city-in-becoming (Addie, 2016; Gupta, 2018; Harris, 2013). The work of (people as) infrastructure always exists in relation to specific actors and organized practices within particular socio-cultural contexts (Star, 1999 , p. 380). Its presence or absence is relational and differentially felt through material or symbolic processes of connection or bypassing (Graham and Marvin, 2001; Sawyer et al., 2021). These processes are not a purely geographic: they express broader moments of structural, political, and epistemic violence that I will term infrastructural alienation.

\section{Infrastructural Alienation and Dead Labor}

One of the key insights emerging from the 'infrastructure turn' is that in materializing particular characteristics, mobilities, and ideologies, infrastructures stabilize social relations within a reified world of things. Infrastructure may appear to direct and determine the timing and rhythms of everyday life "making it seem that living people are mere extensions of those [artefacts], and extensions of a network" (Kirsch and Mitchell, 2004, p. 701). But infrastructures are both a general precondition that make social activities possible and a social product in and of themselves. And as a social product, infrastructures are alienable from those who produce them; not just in terms of the material outcomes of these labor processes - the roads, pipelines, and cables etc. that may be commodified, privatized, or splintered for the public commons (Gioielli, 2011; Graham and Marvin, 2001) - but the social practices, routines, and opportunities that they make possible. Drawing on the work of Don Mitchell (2000, 2003, 2012), I suggest reading infrastructure through a historical materialist lens to highlight how they 'always possess a definite 'historical and moral element' which 
often appears as a set of 'natural' and 'necessary wants' but which is, in fact, a product of past social struggle - dead labor" (Mitchell, 2003, p. 239).

Marx (1973, pp. 461-462) introduced the term 'dead labor' to: (1) conceptualize the past labor power ossified in commodities, machinery, and technology; and (2) theorize a dialectical social relation with 'living labor'; the people who produce material commodities and abstract value by animating dead labor. Dead labor viscerally articulates the nature of capitalist exploitation. In its impulse to produce and absorb surplus value "capital is dead labor, that vampire-like, only lives by sucking living labor, and lives the more, the more labor it sucks" (Marx, 1976, p. 342). Marx's metaphorical use of dead labor is certainly evocative, but as Mitchell (2000) has argued, it is also generative in more-than-metaphorical terms, as workers literally become dead laborers (Tyner and Colucci, 2015, pp. 1093-4). First, it captures "the violence of abstraction in capitalist modernity that transforms the productive body into a technology of calorific inputs and outputs" - i.e. reducing the body to an infrastructure of circulation and accumulation (Andueza et al., 2020, p. 1; also Marx, 1976, p. 364). Second, it offers a means for us to think through how social relations, everyday practices, and labor power become reified in a world of infrastructural things. Infrastructure does not just appear: it. It is produced. And with this, it embodies the social relations and contradictions of its production. Consequently, "the non-human can have very real material social effects" as a result of how 'things as such' are brought into being (Kirsch and Mitchell, 2004, pp. 688, 702). Third and following, the concept of dead labor, as a social relation, enables Marx to demonstrate how under capitalism, past, accumulated, materialized labor comes to dominate immediate experience and governance of living labor in the present (Marx, 1902, p. 38). As labor is ossified in the commodities it produces, "the object which labor produces - labor's product - confronts it as something alien, as a power independent of the producer" (Marx, 1988, p. 71). In contrast to the potentially monstrous socio-technical hybrids of cyborg urbanization (Gandy, 2005) or post-structural non-human 
infrastructural ontologies (Amin and Thrift, 2017; Barua, 2021; McFarlane, 2011), infrastructure understood as dead labor rises up against alienated living labor as hostile oppositional force that constrain our actions and impoverish human life (Kirsch and Mitchell, 2004; Marx, 1988).

From surface appearances, infrastructures say little about the labor that makes them or the conditions of production they internalize (after Mitchell, 2003, p. 235). The concept of dead labor attunes us to the exploitative relations of production and the collective, affective dimensions of infrastructural alienation they invoke. Living labor(ers), on the one hand, may be immiserated through producing urban infrastructures that they will never use or will have immediate detrimental impacts on their quality of life. Dead labor ossified in luxury residential towers and condo developments drives (globalized) affordable housing crises and engenders economic, social, and cultural displacement for low income and communities of color (Madden and Marcuse, 2016). Elsewhere, the development of premium transportation systems shatters communities and bypasses territorial regulations in the name of regional connectivity and competitiveness (Sawyer et al., 2021; Young and Keil, 2010). On the other hand, the dead labor of previous urbanization and accumulation regimes opposes living labor as barriers to health, economic well-being, and community development (at least until they can be replaced or repurposed for bourgeois consumption This often has deadly racialized and classed consequences - as tragically evidenced in infrastructural injustices fostered by the US pipeline crisis from Camden, New Jersey to Flint, Michigan (Inwood, 2018; Silver, 2019).

At the same time, living labor is also frequently injured or killed as a direct result producing, working on, and animating the dead labor of urban infrastructure. Here, premature death is both literal and discursive, evidenced from Du Bois's (1962) critique of the racial dehumanization of "the black worker qua plantation slave as fixed capital - or, dead labor" (Jobson, 2021, p. 226) to the over 6,5000 migrant workers who have died building stadiums, roads, and a new city for Qatar to host the 
2022 FIFA World Cup (Pattison et al., 2021). As Tyner and Colucci assert, we must therefore recognize the danger that not only are laborers alienated from the products of their labor, but through processes of reification, "they may also become alienated - indifferent - to those other living bodies - deemed 'unproductive' or irresponsible' - around them [facilitating an] attitude and acceptability of 'letting die' or 'taking life”' (2015, p.1094).

\section{Confronting Infrastructure as Dead Labor}

So what can we gain by critically reading people as infrastructure against the notion of dead labor? People as infrastructure enables us to see how marginalized urban lives are reproduced and upgraded when cleaved from the formalized provision of services and amenities. The concept draws attention to the people and places left by the wayside of modern networked metropolis, allowing us to document acts of resistance, solidarity, and belonging, even in places where individuals and groups have "[failed] to secure themselves within any durable context" (Simone, 2004, p. 419). As an analytic frame, dead labor collapses the distinction between material and social infrastructure. In doing so, it deepens our understanding of the logics and structural conditions under which marginalized infrastructural lives are made by: (1) connecting people as infrastructures' ephemeral arrangements (and the particular ways of being-in-the-world they make possible) to more entrenched socio-political permanences and privileged forms of urban knowledge; (2) positioning processes of direct and structural infrastructural violence as an essential component of the people as infrastructure provocation; and (3) centralizing social and material alienation as vital mechanisms cleaving communities in 'the background' from the infrastructures supporting urban lives and livelihoods. Dead labor ossified in the material world simultaneously gives rise to particular articulations of people as infrastructure, facilitates their resistive actions, and frames the sociomaterial realities that situate this politics - while becoming its abhorrent co-presence in urbanized 
places. Bridging political economic critique and empathetic ethnographic investigation at the intersection of these frames offers a potentially generative terrain to aid us in the conceptual and political tasks of "re-evaluat[ing] the commonsense workings of violence and death and re-think[ing] analyses of injustice that re-isolate the dispossessed" (McKittrick, 2011, p. 960).

\section{Conclusion}

The world of infrastructure is not a cold, dead place. The concept of people as infrastructure has performed a profound role in "[restoring] narrative to what appears dead" in our urban infrastructural landscapes (Star, 1999, p. 377). Yet, following Mitchell, we may benefit from "[being] more alive (as it were) to dead labor in [infrastructure]: what it is, what it means, and how it is contested" (2000, p. 764). Our cities and their infrastructures are figuratively and literally built on the bodies of alienated laborers at the same time as we rely on their adaptive and improvised social infrastructures to buttress the operation of urban socio-technical systems. Bringing the concept of people as infrastructure into critical dialogue with notions of infrastructural violence, alienation and dead labor is therefore, I suggest, fruitful in two ways. First, it highlights the living labor that underpins the production of the infrastructural systems that urban life depends on but which are increasingly black-boxed and automated. This moves beyond thick descriptions of the adaptive and necessary means through which people secure their livelihoods to foreground the tensions and contradictions in an extant politics of urban infrastructure that "operates not as a locus of mediation and dialogue among differing experiences, claims, and perspectives but as a proliferation of technical standards by which every citizen's capacities are to be compared and judged" (Simone, 2004, p. 420). Second, picking up the thrust of Simone's subaltern urbanism, it forces us think through the ways in which living labor and urban life may be freed from the abstractions and alienation of capitalist 
urbanization to find and create new values, both as a means to live within the cracks of colonizing forces, and as a means to transgress and dismantle them.

The dead labor embodied in urban infrastructure may be dominant but it does not completely dominate living labor in reproducing city space and urban life. As Doherty and Brown suggest, "infrastructure is not just dead labor that takes the form of capital intensive technical systems like electricity grids and road networks. Infrastructure's vitality depends on the ways that it enrolls human bodies and living human labor in the daily work of maintenance and repair” (2019, p. 8). De Coss-Corzo’s (2020) ethnographic research on Mexico City Water System provides an example of the 'patchwork' ways through which repair labor not only maintains and remakes water infrastructure, but invokes new logics of adaptation that intentionally and incrementally remodel previously sanctioned arrangements. Such ad hoc work manifests as an infrastructure of endurance and hope, which Simone captures in his description of inner city Johannesburg as:

a launching pad not only for better livelihoods within the inner city but also for excursions into a broader world... a domain that few want to belong to or establish roots in... [one which] keeps alive residents' hopes for stability somewhere else, even as it cultivates within them a seemingly permanent restlessness and capacity to make something out of the city (2004, pp. 428, 425).

We can find emancipatory potential in the 'minimal difference' produced through the rhythmic repetitions of people as infrastructure (following Lefebvre, 2004). The work of infrastructural maintenance and repair - and the capacity for radical incrementalism to take hold here (Lawhon, Ernstson, and Silver, 2014) - may serve as a foundation for realizing maximal, qualitatively distinct, forms of difference and, ultimately, social transformation (Kipfer, 2008, pp. 203-204). Working across performative and structural epistemic positions validates the divergent individual and collective experiences underpinning the global networked metropolis but further illustrates how 
everyday urban practice confronts and negotiates the ever-present specter of dead labor. With this, the provocation of people as infrastructure tantalizingly situates the potentiality of liberating urban life from the poverty of infrastructural alienation on the horizon. 


\section{References:}

Addie, J.-P.D. (2016). On the road to the in-between city: Excavating peripheral urbanization in Chicago's 'Crosstown Corridor'. Environment and Planning A, 48(5), 825-843.

Addie, J.-P.D., Glass, M.R., and Nelles, J. (2019). Regionalizing the infrastructure turn: A research agenda. Regional Studies, Regional Science, 7(1), 10-26.

Amin, A., and Thrift, N. (2017). Seeing like a city. Cambridge: Polity Press.

Anand, N. (2017). Hydraulic city: Water and the infrastructures of citizenship in Mumbai. Durham: Duke University Press.

Anand, N., Gupta, A., and Appel, H. (Eds.). (2018). The promise of infrastructure. Durham: Duke University Press.

Andueza, L., Davies, A., Loftus, A., and Schling, H. (2020). The body as infrastructure. Environment and Planning E: Nature and Space, OnlineFirst, DOI:10.1177/2514848620937231.

Angelo, H., and Hentschel, C. (2015). Interactions with infrastructure as windows into social worlds: A method for critical urban studies. CITY, 19(2-3), 306-312.

Arboleda, M. (2020). Planetary mine: Territories of extraction under late capitalism. London: Verso.

Barnes, J. (2017). States of maintenance: Power, politics, and Egypt's irrigation infrastructure. Environment \& Planning D: Society and Space, 35(1), 146-164.

Barua, M. (2021). Infrastructure and non-human life: A wider ontology. Progress in Human Geography, Online First, DOI:10.1177/0309132521991220.

Calderia, T.P.R. (2017). Peripheral urbanization: Autoconstruction, transversal logics, and politics in cities of the global south. Environment \& Planning D: Society and Space, 35(1), 3-20.

Chattopadhyay, S. (2012). Unlearning the city: Infrastructure in a new optical field. Minneapolis: University of Minnesota Press. 
Coss-Corzo, D. (2020). Patchwork: Repair labor and the logics of infrastructure adaptation in Mexico City. Environment \& Planning D: Society and Space, OnlineFirst, DOI:10.1177/0263775820938057.

Coward, M. (2008). Urbicide: The politics of urban destruction. New York: Routledge.

Cowen, D. (2014). The deadly life of logistics: Mapping violence in global trade. Minneapolis: University of Minnesota Press.

Cowen, D. (2020). Following the infrastructure of empire: Notes on cities, settler colonialism, and method. Urban Geography, 41(4), 469-486.

Degani, M. (2018). Shock humor: Zaniness and the freedom of permenant improvisation in urban Tanzania. Cultural Anthropology, 33(3), 473-498.

Dodson, J. (2017). The global infrastructure turn and urban practice. Urban Policy and Research, 35(1), $87-92$.

Doherty, J. (2017). Life (and limb) in the fast-lane: Disposable people as infrastructure in Kampala's boda boda industry. Critical African Studies, 9(2), 192-209.

Doherty, J., and Brown, K. (2019). Labor laid waste: An introduction to the special issue on waste work. International Labor and Working Class History, 95(Spring), 1-17.

DuBois, W.E.B. (1962). Black reconstruction in America, 1860-1880. New York: The Free Press.

Edwards, P. (2003). Infrastructure and modernity: Force, time, and social organization in the history of sociotechnical systems. In T.J. Misa, P. Brey, and A. Feenberg (Eds.), Modernity and technology. Cambridge: MIT Press.

Enns, C., and Bersaglio, B. (2020). On the coloniality of 'new' mega-infrastructure projects in East Africa. Antipode, 52(1), 101-123.

Filion, P., and Keil, R. (2017). Contested infrastructure: Inequity and innovation in the global suburb. Urban Policy and Research, 35(1), 7-19. 
Gabrys, J. (2011). Digital rubbish: A natural history of electronics. Ann Arbor: University of Michigan Press.

Gandy, M. (2005). Cyborg urbanization: Complexity and monstrosity in the contemporary city. International Journal of Urban and Regional Research, 29(1), 26-49.

Gioielli, R. (2011). "We must destroy you to save you" Highway construction and the city as a modern commons. Radical History Review, 2011(109), 62-82.

Graham, S. (2010). Cities under siege: The new military urbanism. London: Verso.

Graham, S., and Marvin, S. (2001). Splintering urbanism: Networked infrastructures, technological mobilities and the urban condition. New York: Routledge.

Graham, S., and McFarlane, C. (Eds.). (2015). Infrastructural lives: Urban infrastructure in context. New York: Routledge.

Gupta, A. (2018). The future in ruins: Thoughts on the temporality of infrastructure. In N. Anand, A. Gupta, and H. Appel (Eds.), The promise of infrastructure (pp. 62-79). Durham: Duke University Press.

Harris, A. (2013). Mumbai's underworld: Life beneath transport infrastructure. Moving Worlds, 13, 151-160.

Harvey, P., and Knox, H. (2016). Roads: An anthropology of infrastructure and expertise. New York: Cornell University Press.

Hearne, A., Holbrand, M., and Wastell, S. (Eds.). (2007). Thinking through things: Theorizing artefacts ethnographically. London: Routledge.

Howe, C., Lockrem, J., Appel, H., Hackett, E., Boyer, D., Hall, R., Schneider-Mayerson, M., Pope, A., Gupta, A., Rodwell, E., Ballestro, A., Durbin, T., el-Dahdah, F., Long, E., and Mody, C. (2015). Paradoxical infrastructures: Ruins, retrofit, and risk. Science, Technology, and Human Values, 41(6), 547-565. 
Inwood, J.F. (2018). "It is the innocence which constitutes the crime": Political geographies of white supremacy, the construction of white innocence, and the Flint water crisis. Geography Compass, 12(3), e12361.

Jobson, R.C. (2021). Dead labor: On racial capital and fossil capital. In D. Jenkins and J. Leroy (Eds.), Histories of racial capitalism (pp. 215-230). New York: Columbia University Press.

Jonas, A.E.G., While, A., and Gibbs, D. (2010). Managing infrastructural and service demands in new economic spaces: The new territorial politics of collective provision. Regional Studies, 44(2), 183-200.

Kinder, K. (2016). DIY Detroit: Making do in a city without services. Minneapolis: University of Minnesota Press.

Kipfer, S. (2008). How Lefebvre urbanized Gramsci: Hegemony, everyday life and difference. In K. Goonewardena, S. Kipfer, R. Milgrom, and C. Schmid (Eds.), Space, difference, everyday life: Reading Henri Lefebvre (pp. 193-211). New York: Routledge.

Kipfer, S. (2018). Pushing the limits of urban research: Urbanization, pipelines and counter-colonial politics. Environment \& Planning D: Society and Space, 36(3), 474-493.

Kirkpatrick, L.O., and Smith, M.P. (2011). The infrastructural limits to growth: Rethinking the urban growth machine in times of fiscal crisis. International Journal of Urban and Regional Research, 35(5), 477-503.

Kirsch, S., and Mitchell, D. (2004). The nature of things: Dead labor, non human actors, and the persistence of Marxism. Antipode, 36(4), 687-705.

Kooy, M., and Bakker, K. (2008). Splintered networks: The colonial and contemporary water of Jakarta. Geoforum, 39(6), 1843-1858.

Larkin, B. (2013). The politics and poetics of infrastructure. Annual Review of Anthropology, 42, 327343. 
Lawhon, M., Ernstson, H., and Silver, J. (2014). Provincializing urban political ecology: Towards a situated UPE through African urbanism. Antipode, 46(2), 497-516.

Lawhon, M., Nilsson, D., Silver, J., Ernstson, H., and Lwasa, S. (2018). Thinking through heterogeneous infrastructure configurations. Urban Studies, 55(4), 720-732.

Lawhon, M., and Truelove, Y. (2020). Disambiguating the southern urban critique: Propositions, pathways and possibilities for a more global urban studies. Urban Studies, 57(1), 3-20.

Lefebvre, H. (2004). Rhythmanalysis: Space, time and everyday life. London: Bloomsbury.

Lemanski, C. (Ed.) (2020). Citizenship and infrastructure: Practices and identities of citizens and the state. New York: Routledge.

Madden, D., and Marcuse, P. (2016). In defense of housing. London: Verso.

Maringanti, A., and Jonnalagadda, I. (2015). Rent gap, fluid infrastructure and population excess in a gentrifying neighborhood. CITY, 19(2-3), 365-374.

Marx, K. (1902). Wage-labor and capital. New York: New York Labor News Company.

Marx, K. (1973). Grundrisse: Foundations of the critique of political economy. London: Penguin.

Marx, K. (1976). Capital: A critique of political economy, volume 1. Hammondsworth: Penguin.

Marx, K. (1988). The economic and philosophical manuscripts of 1844. Amherst: Prometheus Books.

McFarlane, C. (2011). Assemblage and critical urbanism. CITY, 15(2), 204-224.

McFarlane, C., and Rutherford, J. (2008). Political infrastructures: Governing and experiencing the fabric of the city. International Journal of Urban and Regional Research, 32(2), 363-374.

McFarlane, C., \& Silver, J. (2017). Navigating the city: Dialectics of everyday urbanism. Transactions of the Institute of British Geographers, 42(3), 458-471.

McKittrick, K. (2011). On plantations, prisons, and a black sense of place. Social and Cultural Geography, 12(8), 947-963. 
Mitchell, D. (2000). Dead labor: The geography of workplace violence in America and beyond. Environment \& Planning A, 32(5), 761-768.

Mitchell, D. (2003). Dead labor and the political economy of landscape - California living, California dying. In K. Anderson, M. Domosh, S. Pile, and N. Thrift (Eds.), Handbook of cultural geography (pp. 233-248). Thousand Oaks: Sage.

Mitchell, D. (2012). They saved the crops: Labor, landscape, and the struggle over industrial farming in Bracero-era California. Athens: University of Georgia Press.

Niranjana, R. (2021). Between fragments and ordering: Engineering water infrastructure in a postcolonial city. Geoforum, 119, 1-10.

O’Brien, P., O’Neill, P., and Pike, A. (2019). Funding, financing and governing urban infrastructures. Urban Studies, 56(7), 1291-1303.

Pattisson, P., McIntyre, N., Mukhtar, I., Eapen, N., Mukhtar, I., Bhuyan, M.O.U., Bhattarai, U., and Piyari, A. (2021). Revealed: 6,500 migrant workers have died n Qatar as it gears up for World Cup. The Guardian. Retrieved from The Guardian website: https://www.theguardian.com/global-development/2021/feb/23/revealed-migrant-workerdeaths-qatar-fifa-world-cup-2022

Pilo', F., and Jaffe, R. (2020). Introduction: The political materiality of cities. City and Society, 32(1), 822.

Ramakrishnan, K., O’Reilly, K., and Budds, J. (2020). Between decay and repair: Embodied experiences of infrastructure's materiality. Environment \& Planning E: Nature and Space, Online First, DOI:10.1177/2514848620980597.

Ranganathan, M. (2014). Paying the pipes, claiming citizenship: Political agency and water reforms at the urban periphery. International Journal of Urban and Regional Research, 38(2), 590-608. 
Rodgers, D., and O’Neill, B.O. (2012). Infrastructural violence: Introduction to the special issue. Ethnography, 13(4), 401-412.

Roy, A. (2009). The 21st century metropolis: New geographies of theory. Regional Studies, 43(6), 819830.

Sawyer, L., Schmid, C., Streule, M., and Kallenberger, P. (2021). Bypass urbanism: Re-ordering center-periphery relations in Kolkata, Lagos and Mexico City. Environment and Planning A, OnlineFirst, DOI 10.1177/0308518X20983818.

Schindler, S., and Kanai, M. (2021). Getting the territory right: Infrastructure-led development and the re-emergence of spatial planning strategies. Regional Studies, 55(1), 40-51.

Silver, J. (2019). Decaying infrastructure in the post-industrial city: An urban political ecology of the US pipeline crisis. Environment and Planning E: Nature and Space, OnlineFirst, DOI:10.1177/2514848619890513.

Simone, A.M. (2004). People as infrastructure: Intersecting fragments in Johannesburg. Public Culture, 16(3), 407-429.

Simone, A.M. (2015). Relational infrastructures in postcolonial urban worlds. In S. Graham and C. McFarlane (Eds.), Infrastructural lives: Urban infrastructure in context (pp. 17-38). New York: Routledge.

Simone, A.M. (2018). Improvised lives: Rhythms of endurance in an urban south. Cambridge: Polity Press.

Simone, A.M. (2019). Maximum exposure: Making sense in the background of extensive urbanization. Environment \& Planning D: Society and Space, 37(6), 990-1006.

Simone, A.M. (2020). The Black city? International Journal of Urban and Regional Research. Retrieved from IJURR.org website: https://www.ijurr.org/spotlight-on/race-justice-and-the-city/the-

\section{black-city/}

Star, S.L. (1999). The ethnography of infrastructure. American Behavioral Scientist, 43(3), 377-391. 
Sultana, F. (2020). Embodied intersectionalities of urban citizenship: Water, infrastructure, and gender in the Global South. Annals of the Association of American Geographers, 110(5), 14071424.

Thieme, T.A. (2015). Turning hustlers into entreprenuers, and social needs into market demands: Corporate-community encounters in Nairobi, Kenya. Geoforum, 59, 228-239.

Tonkiss, F. (2013). Austerity urbanism and the makeshift city. CITY, 17(3), 312-324.

Tyner, J. (2019). Dead labor: Toward a political economy of premature death. Minneapolis: University of Minnesota Press.

Tyner, J., and Colucci, A. (2015). Bare life, dead labor, and capital(ist) punishment. $A C M E: A n$ International E-Journal for Critical Geographies, 14(4), 1083-1099.

Wiig, A., and Silver, J. (2019). Turbulent presents, precarious futures: Urbanization and the deployment of global infrastructure. Regional Studies, 53(6), 912-923.

Young, D., and Keil, R. (2010). Reconnecting the disconnected: The politics of infrastructure in the in-between city. Cities, 27(2), 87-95. 